\title{
Effects of Parity and Supply of Rumen-Degraded and Undegraded Protein on Production and Nitrogen Balance in Holsteins
}

\author{
S. A. Flis and M. A. Wattiaux \\ Department of Dairy Science, University of Wisconsin, Madison 53706
}

\section{ABSTRACT}

Eight Holstein cows (4 primiparous and 4 multiparous) were used in a replicated $4 \times 4$ Latin square design to determine milk production response and $\mathrm{N}$ balance when diets had no NRC-predicted excess of rumen-undegradable protein (RUP) or rumen-degradable protein (RDP), $10 \%$ RUP excess, $10 \%$ RDP excess, or $10 \%$ excess of both RUP and RDP. Diets were fed as a total mixed ration with (dry matter basis) $25 \%$ alfalfa silage, $25 \%$ corn silage, 19 to $21 \%$ corn grain, and varying proportions of solvent soybean meal and expeller soybean meal as primary sources of supplemental RDP and RUP, respectively. Milk yield and dry matter intake (DMI) were recorded daily, and total collection of feces and urine was completed in the last $3 \mathrm{~d}$ of each 21-d period. Dietary crude protein averaged 17.5 and $18.5 \%$ for the recommended and excess RDP diets, respectively, and 17.3 and $18.4 \%$ for the recommended and excess RUP diets, respectively. When cows were fed excess RUP diets in the form of expeller soybean meal, DMI and milk production increased, but the opposite was true when the diets contained excess $\mathrm{RDP}$ in the form of solvent soybean meal. Milk composition was not affected by RDP, RUP, or by parity, and there were no parity $\times$ RDP interactions for any of the measurements. However, apparent digestibility of neutral detergent fiber, dry matter, and $\mathrm{N}$ increased in multiparous cows but not in primiparous cows because of excess RUP. The increase in the yield of milk $\mathrm{N}$ with excess RUP was not influenced by parity, but multiparous cows retained more of the additional $\mathrm{N}$ apparently absorbed, whereas primiparous cows excreted the additional apparently absorbed $\mathrm{N}$ in the urine. Overall, the difference in urinary $\mathrm{N}$ due to parity $(70 \mathrm{~g} / \mathrm{d})$ was about 4 times greater than the impact of dietary treatments $(17 \mathrm{~g} / \mathrm{d})$. Our results suggest that multiparous cows have either a much larger urea pool or a greater demand to restore body protein mobilized earlier in lactation compared with primiparous cows.

Received October 11, 2004.

Accepted February 24, 2005.

Corresponding author: Sally A. Flis; e-mail: flis@whminer.com.
Reduction in urinary $\mathrm{N}$ excretion in commercial dairy herds could be obtained by separately balancing rations for first and later lactations.

(Key words: parity, nitrogen, $\mathrm{N}$ balance, environment)

Abbreviation key: $\mathbf{E D}=$ excess level of RDP, EU = excess level of RUP, NAR = nitrogen apparently retained, $\mathbf{R U}=$ recommended level of RUP, $\mathbf{R D}=$ recommended level of RDP, $\mathbf{S}=$ square.

\section{INTRODUCTION}

Due to increasing societal pressure to improve the environmental performance of livestock operations, research is currently being directed toward improving the efficiency of $\mathrm{N}$ use by lactating dairy cows to reduce unnecessary loss of N in urine (NRC, 2001). Close management of dietary protein is needed to maximize profits and to minimize the increased risk of environmental damage associated with excessive $\mathrm{N}$ excretion in urine and feces (Wu and Satter, 2000). At low N intake, the primary route of $\mathrm{N}$ excretion is through the feces, but as $\mathrm{N}$ intake increases above $400 \mathrm{~g} / \mathrm{d}$, urinary $\mathrm{N}$ increases exponentially, thus increasing the vulnerability of the $\mathrm{N}$ to ammonia emission and air pollution (Castillo et al., 2001). Recent results showed no production benefits in feeding rations above $16.7 \%$ CP in midlactation (Broderick, 2003) or above NRC recommendations of 16.5 and $16.2 \% \mathrm{CP}$ in alfalfa silage- and corn silage-based diets the first $100 \mathrm{~d}$ of lactation (Wattiaux and Karg, 2004a). These reports also showed that the unutilized portion of the $\mathrm{N}$ in rations with more than $17.0 \% \mathrm{CP}$ is lost primarily as urinary urea-N.

Most of this research, however, has been done with multiparous cows only (Castillo et al., 2001; Broderick et al., 2002; Wattiaux and Karg, 2004a). Few studies have examined in detail the response of primiparous and multiparous cows to RUP and RDP without partial or complete confounding between protein source and dietary level of RUP or RDP. Davidson et al. (2003) compared the production response of primiparous and multiparous cows on 5 diets that varied in protein level, source, and supply of RUP, and reported results 
by parity, but did not report any significant treatment by parity interactions. Broderick (2003) used spot sampling and marker techniques to measure urinary and fecal $\mathrm{N}$ in multiparous and primiparous cows in a $9 \times$ 9 Latin square design, but did not report or discuss parity effects. Cunningham et al. (1996) used soybased products only to change RUP content of the diet in primiparous and multiparous cows, but did not report N balance data. Kauffman and St-Pierre (2001) compared breed (Holstein vs. Jersey) to assess the impact of animal size on the use of $\mathrm{N}$ and found that there was a difference in $\mathrm{N}$ intake, fecal $\mathrm{N}, \mathrm{N}$ apparently absorbed, urine $\mathrm{N}$, and milk $\mathrm{N}$ due partially to higher DMI by the Holstein cows, but no differences were detected for $\mathrm{N}$ apparently retained (NAR) or the efficiency of conversion of dietary $\mathrm{N}$ to milk $\mathrm{N}$ between breeds. These researchers also reported a breed by dietary CP interaction for urine $\mathrm{N}$. The nature of this interaction remains unclear and raises the question of whether primiparous and multiparous cows would respond differently to excess dietary N. Thus, the objectives of this study were to determine $\mathrm{N}$ balance and production response of primiparous and multiparous Holstein cows fed different levels of RUP and RDP with soy-based by-products as the sole supplemental protein source.

\section{MATERIALS AND METHODS}

\section{Experimental Design}

Four primiparous and 4 multiparous (fifth lactation) Holstein cows were used in a replicated $4 \times 4$ Latin square. Animals were selected on parity and DIM. Primiparous and multiparous cows averaged ( \pm SD) $58 \pm$ 5.1 and $56 \pm 10.9$ DIM, respectively, at the start of the trial. Primiparous cows averaged 26 mo of age at calving. All cows were bred, but no pregnancies were confirmed during the trial. The treatments were arranged in a split-plot design with parity forming the main plots [squares (S)] and dietary treatments forming the subplots. The experimental periods lasted 21 d, with d 17 and 18 used for adaptation to urinary catheters, and d 19 to 21 for sampling and daily total collection of urine and feces.

\section{Diets and Cow Management}

In formulating diets using the NRC (2001) model, it was assumed that the primiparous cows were $30 \mathrm{mo}$ of age, mature weight of $680 \mathrm{~kg}$, current weight of 517 $\mathrm{kg}, 0 \mathrm{~d}$ pregnant, $90 \mathrm{DIM}$, and $34 \mathrm{~kg} / \mathrm{d}$ of milk with $3.3 \%$ fat and $3.0 \%$ protein. The assumptions made for multiparous cows were 55 mo of age, $680 \mathrm{~kg} \mathrm{BW,} 0 \mathrm{~d}$ pregnant, $90 \mathrm{DIM}$, and $45 \mathrm{~kg} / \mathrm{d}$ milk with $3.3 \%$ fat and $3.0 \%$ protein. Diets included approximately $25 \%$ alfalfa silage, $25 \%$ corn silage, and $50 \%$ concentrate mix that included minerals and vitamins (Table 1 ). The CP and NDF of the forages used in formulating the rations were analyzed by near-infrared spectroscopy (UW Soil \& Forage Analysis Laboratory, Marshfield, WI). Experimental rations included recommended levels of RUP and RDP (RU-RD), 10\% RUP excess (EURD) $10 \%$ excess RDP (RU-ED), or 10\% excess of both RUP and RDP (EU-ED). Predicted RUP and RDP balances were adjusted primarily by changing the proportion of soy ingredients in the diet [solvent soybean meal 48, expellers soybean meal (SoyPLUS, Ralston, IA), and soybean hulls]. Thus, the EU-RD diet had the highest level of expellers soybean meal, and the RUED diet had the most solvent soybean meal (Table 1). Corn grain and dried molasses were adjusted to maintain a high level of NFC in all diets in an attempt to supply ruminal microorganisms with sufficient energy and avoid inefficient use of RDP when provided in excess. The level of corn grain and dried molasses was similar in all 4 diets. Sodium bicarbonate was added to avoid rumen acidosis.

Diets were fed as TMR once daily at $0900 \mathrm{~h}$ ad libitum for $10 \%$ refusals. Ingredient mix was adjusted based on weekly DM analysis of forages. Between sampling periods, cows were milked in the parlor with the rest of the research herd at approximately 0500 and $1700 \mathrm{~h}$. However, from d 17 to 21, cows remained in their stalls and were milked with a portable milking unit in the stalls at approximately 0400 and $1600 \mathrm{~h}$. Cows were cared for according to the guidelines of the Research Animal and Resource Committee at the University of Wisconsin-Madison and all experimental procedures were approved.

\section{Sample Collection}

Orts were measured daily and feed offered was adjusted to allow for 5 to $10 \%$ orts. Samples of orts were collected daily on d 19 to 21 of each period and frozen at $-20^{\circ} \mathrm{C}$ for later analysis. Milk weights were recorded daily throughout the trial. Duplicate milk samples were collected from a.m. and p.m. milkings of the 3 sampling days. One sample was sent to AgSource, (Menomonie, WI) for analysis with the CombiFoss 5000 (Foss Electric, Hillerød, Denmark). The MilkoScan 4000 was used to determine milk fat and protein (AOAC, 1990), and milk urea $\mathrm{N}$ using the differential $\mathrm{pH}$ method as a standard. The Fossomatic 5000 was used to count somatic cells by flow cytometry (AOAC, 1999). The other sample was frozen at $-20^{\circ} \mathrm{C}$ for later analysis of protein. Total fecal production was measured on d 19 to 21. Feces were shoveled into contain- 
Table 1. Ingredients and nutrient composition of experimental diets.

\begin{tabular}{|c|c|c|c|c|}
\hline \multirow[b]{2}{*}{ Item } & \multicolumn{4}{|c|}{ Treatments $^{1}$} \\
\hline & RU-RD & EU-RD & RU-ED & EU-ED \\
\hline \multicolumn{5}{|l|}{ Ingredients, $\%$ of $\mathrm{DM}$} \\
\hline Alfalfa silage & 25.40 & 25.10 & 25.90 & 25.41 \\
\hline Corn silage & 25.40 & 25.10 & 25.90 & 25.41 \\
\hline Corn grain, dried, ground & 20.40 & 20.15 & 19.31 & 21.41 \\
\hline Molasses, dried, beet sugar & 4.18 & 4.18 & 4.06 & 4.39 \\
\hline Soybean meal, solvent ( $48 \% \mathrm{CP})$ & 6.60 & 6.05 & 11.75 & 11.31 \\
\hline Soybean meal, expellers ${ }^{2}$ & 5.06 & 7.49 & 1.22 & 4.12 \\
\hline Soybean, hulls & 10.09 & 9.32 & 9.07 & 5.13 \\
\hline Limestone $^{4}$ & 0.00 & 0.09 & 0.21 & 0.15 \\
\hline Salt $+\mathrm{Se}^{4}$ & 0.65 & 0.42 & 0.41 & 0.58 \\
\hline Vitamin $\operatorname{mix}^{3,4}$ & 1.07 & 0.94 & 1.07 & 1.09 \\
\hline Dicalcium phosphate ${ }^{4}$ & 0.54 & 0.56 & 0.54 & 0.30 \\
\hline Sodium bicarbonate ${ }^{4}$ & 0.65 & 0.56 & 0.54 & 0.69 \\
\hline \multicolumn{5}{|l|}{ Nutrient composition, \% of DM } \\
\hline $\mathrm{CP}$ & 17.0 & 18.0 & 17.6 & 18.7 \\
\hline NDF & 26.0 & 26.9 & 25.4 & 23.9 \\
\hline Forage, NDF & 17.2 & 17.0 & 17.5 & 17.2 \\
\hline $\mathrm{ADF}$ & 18.6 & 19.0 & 19.0 & 17.0 \\
\hline NFC & 45.4 & 43.8 & 45.4 & 46.0 \\
\hline Starch & 32.2 & 27.9 & 31.1 & 31.4 \\
\hline $\mathrm{NDICP}^{5}$ & 1.29 & 1.47 & 1.06 & 1.20 \\
\hline $\mathrm{ADICP}^{6}$ & 1.30 & 0.78 & 1.07 & 1.80 \\
\hline Fatty acids & 2.72 & 2.65 & 2.41 & 2.54 \\
\hline Ash & 9.21 & 9.13 & 9.29 & 9.02 \\
\hline $\mathrm{Ca}$ & 0.60 & 0.60 & 0.70 & 0.60 \\
\hline $\mathrm{P}$ & 0.40 & 0.40 & 0.40 & 0.40 \\
\hline \multicolumn{5}{|c|}{$\begin{array}{l}{ }^{1} \mathrm{RU}=\text { Recommended level of RUP, } \mathrm{EU}=\text { excess level of } \mathrm{RUP}, \mathrm{RD}=\text { recommended level of } \mathrm{RDP}, \mathrm{ED}= \\
\mathrm{xcess} \text { level of RDP. }\end{array}$} \\
\hline \multicolumn{5}{|l|}{${ }^{2}$ SoyPLUS, Ralston, IA. } \\
\hline \multicolumn{5}{|c|}{${ }^{3}$ Vitamin mix contained $1,500,000 \mathrm{IU}$ vitamin A; 500,000 IU vitamin D; and $5000 \mathrm{IU}$ vitamin E. } \\
\hline \multicolumn{5}{|c|}{$\begin{array}{l}{ }^{4} \text { The mineral and vitamin premix was adjusted according to the supply of other dietary ingredients to } \\
\text { meet dietary requirements rather than using a "flat" percentage across all diets. }\end{array}$} \\
\hline \multicolumn{5}{|c|}{${ }^{5} \mathrm{NDICP}=$ Neutral detergent insoluble CP. } \\
\hline${ }^{6} \mathrm{ADICP}=$ Acid detergent insol & & & & \\
\hline
\end{tabular}

ers and weighed twice a day. Duplicate samples were taken at each sampling time. One sample was dried at $60^{\circ} \mathrm{C}$ for $36 \mathrm{~h}$ and the other was frozen at $-20^{\circ} \mathrm{C}$ for later analysis. Urine collection was conducted on $\mathrm{d}$ 19 to 21 using indwelling catheters $(75-\mathrm{mL}$ balloon lubricious catheter, C. R. Bard, Inc., Covington, GA). Five hundred milliliters and $400 \mathrm{~mL}$ of $50 \% \mathrm{H}_{2} \mathrm{SO}_{4}$ were added to collection carboys for multiparous and primiparous cows, respectively. The volume of $50 \%$ $\mathrm{H}_{2} \mathrm{SO}_{4}$ added to the carboys was determined by measuring $\mathrm{pH}$ after 12 and $24 \mathrm{~h}$ of collection on $\mathrm{d} 17$ and 18 of period 1 to ensure a $\mathrm{pH}$ below 3.0. Urine volume was measured twice daily at milking time and samples were frozen at $-20^{\circ} \mathrm{C}$ for later analysis. Two hundred milliliters of rumen fluid was collected from 5 different locations in the rumen with a metal filter probe through ruminal cannula every $4 \mathrm{~h}$ for a 24 -h period starting $4 \mathrm{~h}$ after feeding on d 18. One-milliliter subsamples were mixed with $0.02 \mathrm{~mL}$ of $50 \%$ trichloroacetic acid and frozen at $20^{\circ} \mathrm{C}$ for later analysis of ammonia (Chaney and Marbach, 1962). Body weight was calculated as the average of measurements performed in the p.m. of $d 18$ and the a.m. of $d 21$.

\section{Sample Analysis}

Feed, milk, urine, and fecal samples. Orts samples, alfalfa silage $(n=9)$, corn silage $(n=8)$, concentrate mix ( $\mathrm{n}=4$ for each mix), and fecal samples were dried at $60^{\circ} \mathrm{C}$ and ground to pass a 1-mm screen (Wiley mill, Arthur H. Thomas, Philadelphia, PA). Orts and fecal samples were composited for each cow by period based on the fresh weight of orts or feces produced from each collection day. Dry matter content was determined by drying at $100^{\circ} \mathrm{C}$ for $24 \mathrm{~h}$; ash content was determined at $500^{\circ} \mathrm{C}$ for $16 \mathrm{~h}$. Organic matter was calculated as 100 - ash. Crude protein was determined by microKjeldahl (AOAC, 1990). For alfalfa silage, corn silage, concentrate mix, and fecal samples, NDF was determined according to Van Soest et al. (1991) using $\alpha$-amylase (\# FAA; Ankom Technology, Fairport, NY) and sodium sulfite. Calculation of NDF concentra- 
tion included a correction for ash content according to Mertens (1999) and adapted for Ankom ${ }^{200}$ Fiber Analyzer (Ankom Technology). Samples of alfalfa silage, corn silage, and concentrate mix were also analyzed for ADF using the method described by Goering and Van Soest (1970) and adapted for the Ankom ${ }^{200}$ Fiber Analyzer (Ankom Technology). In addition, $\mathrm{N}$ bound to neutral and acid detergent residues were determined by microKjeldahl (AOAC, 1990) and expressed as neutral detergent insoluble $\mathrm{CP}$ and acid detergent insoluble CP. Fatty acids were determined following the procedure described by Sukhija and Palmquist (1988) and represented the sum of $\mathrm{C}_{14}$ to $\mathrm{C}_{18}$. The NFC fraction was calculated as $100-[(\mathrm{NDF}-$ neutral detergent insoluble $\mathrm{CP}$ ) + ether extract + $\mathrm{CP}+\mathrm{ash}$, where ether extract was calculated as fatty acids plus one (p. 14; NRC, 2001). Starch was determined by gelatinization procedure using $\alpha$-amylase (Sigma A3306; Sigma Chemical Co., St. Louis, MO), amyloglucosidase (Sigma A3514; Sigma Chemical Co.), and sodium acetate buffer adapted from Holm et al. (1986) followed by a colorimetric assay for glucose as outlined by Karkalas (1985). Urine and milk samples were composited based on production for each cow each period. Total milk $\mathrm{N}$ was determined by macroKjeldahl (AOAC, 1990). Urine $\mathrm{N}$ was determined by microKjeldahl (AOAC, 1990).

Rumen samples. The $\mathrm{pH}$ of ruminal fluid was determined within 1 min of collection with an Horiba compact $\mathrm{pH}$ meter (B-213; Spectrum Technologies, Inc., Plainfield, IL). Rumen ammonia was determined using the preserved samples as outlined by Bal et al. (2000). Daily averages for ruminal $\mathrm{pH}$ and ammonia concentration were calculated as the mean of the 6 equally spaced observations.

Forage RUP and RDP determination. Alfalfa silage $(n=9)$ and corn silage $(n=8)$ samples were dried at $60^{\circ} \mathrm{C}$ and ground to pass a $2-\mathrm{mm}$ screen (Wiley mill, Arthur H. Thomas). Composite samples $[5 \pm 0.07 \mathrm{~g}( \pm$ $\mathrm{SD})]$ of these 2 forages were placed in $9 \times 18 \mathrm{~cm}$ Dacron bags (Balson-Erlanger, New York, NY) with nominal pore size of $52 \pm 5 \mu \mathrm{m}$. Incubation times of $0,2,4,8$, $16,24,48$, and $72 \mathrm{~h}$ were used (NRC, 2001). Two cows were fed a diet of $25 \%$ alfalfa silage, $25 \%$ corn silage, and $50 \%$ concentrate (DM basis). Bags were soaked, inserted, and washed according to Coblentz et al. (1997; 1998). After rinsing, the bags were dried at $60^{\circ} \mathrm{C}$ for $72 \mathrm{~h}$, and DM and $\mathrm{N}$ were determined as previously described. Kinetic parameters (A, B, and C fractions and $\mathrm{Kd}$, the rate of degradation of the $\mathrm{B}$ fraction) were determined using a nonlinear least square method (Proc NLIN, SAS Institute, 1998) assuming a firstorder kinetic model as outlined in Wattiaux et al. (1994).

\section{Statistical Analyses}

Milk production, percentage and yield of milk components, DMI, nutrient intake, rumen measurements, and total collection data were analyzed using Proc Mixed of SAS (SAS Institute, 1998) according to the following model:

$$
\begin{gathered}
\mathrm{Y}_{\mathrm{ijklm}}=\mu+\mathrm{S}_{\mathrm{i}}+\mathrm{c}_{\mathrm{i}: \mathrm{j}}+\mathrm{P}_{\mathrm{k}}+\mathrm{RUP}_{\mathrm{l}}+\mathrm{RDP}_{\mathrm{m}}+\mathrm{RUP} \\
\times \mathrm{RDP}_{\mathrm{lm}}+\mathrm{S} \times \mathrm{RUP}_{\mathrm{il}}+\mathrm{S} \times \mathrm{RDP}_{\mathrm{im}}+\mathrm{E}_{\mathrm{ijklm}}
\end{gathered}
$$

where $\mu$ = overall mean; $\mathrm{S}_{\mathrm{i}}=$ fixed effect of the ith square (parity), $i=1,2 ; c_{i: j}=$ random effect of the $j$ th cow within the ith square, $\mathrm{j}=1$ to $4 \sim \mathrm{N}\left(0, \sigma_{\mathrm{c}}^{2}\right) ; \mathrm{P}_{\mathrm{k}}=$ fixed effect of the kth period, $\mathrm{k}=1$ to $4 ; \mathrm{RUP}_{1}=$ fixed effect if the lth RUP level, l = 1, 2 (EU diets) vs. (RU diets); $\mathrm{RDP}_{\mathrm{m}}=$ fixed effect of $\mathrm{mth} \mathrm{RDP}$ level, $\mathrm{m}=1,2$ (ED diets) vs. $\left(\mathrm{RD}\right.$ diets); RUP $\times \mathrm{RDP}_{\mathrm{lm}}=$ interaction of the lth RUP level with the mth RDP level, (RU-RD and EU-ED diets) vs. (RU-ED and EU-RD diets); $\mathrm{S} \times$ $R \mathrm{P}_{\mathrm{il}}=$ interaction of the ith square with the lth level of RUP; $\mathrm{S} \times \mathrm{RDP}_{\mathrm{im}}=$ interaction of the ith square with the mth RDP level; and $\mathrm{E}_{\mathrm{ijk} k \mathrm{~m}}=$ error term $\sim \mathrm{N}(0$, $\left.\sigma_{\mathrm{e}}^{2}\right)$.

Statistical significance was declared at $P \leq 0.05$ and tendencies at $P \leq 0.1$. Main effects are reported in the tables, but interactions are reported and discussed in the text.

\section{RESULTS}

\section{Feed and Diet Composition}

Nutrient composition of forages and grain mixes are reported in Table 2 . The $\mathrm{CP}$ content of the alfalfa silage was low in relation to its concentration of NDF and ADF. The CP value for the alfalfa silage in this study was closer to that of a mature alfalfa silage with NDF $>46 \%$ (see Table 15-1 in NRC, 2001). In contrast, the corn silage had a normal CP content but was low in $\mathrm{NDF}$ and ADF. The values reported here were only marginally different from the pretrial measurements. Estimates of the soluble (A fraction), degradable (B fraction), and indigestible (C fraction) percentage of $\mathrm{CP}$ in the alfalfa silage and corn silage were $70 \pm 0.0$ and $69 \pm 0.5,24 \pm 0.7$ and $13 \pm 3.1$, and $9 \pm 0.2$ and 18 $\pm 0.0( \pm \mathrm{SD})$, respectively. The rate of degradation of the $\mathrm{B}$ fraction $\left(\mathrm{h}^{-1}\right)$ for the $\mathrm{CP}$ in alfalfa silage and corn silage was $0.15 \pm 0.06$ and $0.05 \pm 0.01( \pm \mathrm{SD})$, respectively. The calculated RUP and RDP as a percentage of DM was 2.7 (15\% of CP) and 15.2 (85\% of $\mathrm{CP})$ for the alfalfa silage and $2.1(24 \%$ of $\mathrm{CP})$ and 6.6 $(76 \%$ of $\mathrm{CP})$ for the corn silage, respectively. 
Table 2. Nutrient composition of forages and grain mixes.

\begin{tabular}{|c|c|c|c|c|c|c|}
\hline \multirow[b]{2}{*}{ Item } & \multicolumn{2}{|c|}{ Forages $^{1}$} & \multicolumn{4}{|c|}{ Grain mixes $^{2}$} \\
\hline & $\mathrm{AS}$ & CS & RU-RD & EU-RD & RU-ED & EU-ED \\
\hline DM, \% as-fed & $34.4(0.05)$ & $31.4(0.02)$ & 87.1 & 88.2 & 87.6 & 87.4 \\
\hline $\mathrm{CP}$ & $17.9(0.58)$ & $8.7(0.62)$ & 20.8 & 22.7 & 22.2 & 24.3 \\
\hline $\mathrm{RUP}^{3}$ & 2.7 & 2.1 & $\ldots$ & $\ldots$ & $\begin{array}{l}20.4 \\
\ldots\end{array}$ & $\ldots$ \\
\hline $\mathrm{RDP}^{3}$ & 15.2 & 6.6 & & & & \\
\hline $\mathrm{NDF}$ & $33.7(2.18)$ & $33.8(2.50)$ & 17.9 & 19.9 & 16.3 & 13.7 \\
\hline $\mathrm{ADF}$ & $30.4(2.21)$ & $20.3(1.80)$ & 11.5 & 12.6 & 12.1 & 8.3 \\
\hline NFC & 32.6 & 51.0 & 49.2 & 45.6 & 49.4 & 50.4 \\
\hline Ash & $14.3(0.14)$ & $4.9(0.05)$ & 8.8 & 8.6 & 8.9 & 8.4 \\
\hline $\mathrm{NDICP}^{4}$ & $1.3(0.04)$ & $0.7(0.14)$ & 1.6 & 1.9 & 1.1 & 1.4 \\
\hline $\mathrm{ADICP}^{5}$ & $1.0(0.39)$ & $0.6(0.22)$ & 1.8 & 0.8 & 1.3 & 2.8 \\
\hline Fatty acids & $1.8(2.93)$ & $1.3(1.85)$ & 3.9 & 3.8 & 3.3 & 3.6 \\
\hline Starch & $2.6(1.01)$ & $38.6(6.43)$ & 44.1 & 35.4 & 42.4 & 42.5 \\
\hline $\mathrm{Ca}$ & $\ldots$ & $\ldots$ & 0.48 & 0.50 & 0.59 & 0.46 \\
\hline $\mathrm{P}$ & $\ldots$ & $\ldots$ & 0.49 & 0.50 & 0.50 & 0.49 \\
\hline
\end{tabular}

${ }^{1} \mathrm{AS}=$ Alfalfa silage; $\mathrm{CS}=$ corn silage; values in parentheses indicate standard deviation.

${ }^{2} \mathrm{RU}=$ Recommended level of RUP, EU = excess level of RUP, RD = recommended level of RDP, ED = excess level of RDP.

${ }^{3}$ Measured by in situ ruminal incubation.

${ }^{4} \mathrm{NDICP}=$ Neutral detergent insoluble CP.

${ }^{5} \mathrm{ADICP}=$ Acid detergent insoluble $\mathrm{CP}$.

The CP of the grain mixes increased with the addition of RDP or RUP to the diet, with the EU-ED diet having the highest $\mathrm{CP}$ (Table 2). The NDF in the grain mixes was a reflection of their content in soybean hulls and expellers soybean meal, with the latter having half the content of NDF of the former (NRC, 2001).

Differences in the nutrient composition of the rations (Table 1) were due primarily to differences in the chemical analysis of the grain mixes because the percentage of alfalfa and corn silage was similar in all diets. Given similar percentages of corn silage and corn grain in the diets, starch content was expected to be constant. The lower than expected value for the EU-RD diet is difficult to explain, but may be related to error in preparation of certain batches of the grain mix for that particular diet. Overall, the concentration of NFC, fatty acids, and ash was relatively constant among diets.

\section{Body Weight, Intake, Digestibility, and Rumen Measurements}

Body weight. In this trial, multiparous cows weighed $182 \mathrm{~kg}$ more than the primiparous cows (Table 3). Average BW did not differ across dietary treatment, but there was an $\mathrm{S} \times \mathrm{RDP}$ interaction $(P=0.04)$. This interaction was due primarily to a differential response, with multiparous cows gaining $3.8 \mathrm{~kg}$ but primiparous cows losing $10.5 \mathrm{~kg}$ when fed the ED diets. However, observation of individual cow data indicated that this effect was due primarily to 1 of the 4 primipa- rous cows that may have been under stress during the first period. This cow was recovering from a difficult calving, but had improved performance in the 3 subsequent periods.

DM and nutrient intake. There were no $\mathrm{S} \times \mathrm{RDP}$ or $\mathrm{S} \times \mathrm{RUP}$ interactions for DMI and nutrient intake, but DMI differed between parity groups, with the primiparous cows eating $8.7 \mathrm{~kg} / \mathrm{d}$ less than the multiparous cows. Intake of OM, NDF, starch, and NFC followed the same pattern as for DMI (Table 3).

Dry matter intake of cows on EU diets was $2.1 \mathrm{~kg} /$ $\mathrm{d}$ higher compared with the RU diets. In contrast, DMI was $1.2 \mathrm{~kg} / \mathrm{d}$ lower in cows fed the ED diets compared with those fed the RD diets. Intake of OM and NDF showed the same pattern as for DMI. Starch intake was influenced by a RUP $\times$ RDP interaction $(P=0.02)$. Intake of starch was $0.65 \mathrm{~kg} / \mathrm{d}$ higher when cows consumed the RU-RD or the EU-ED diets $(7.4 \mathrm{~kg} / \mathrm{d}) \mathrm{com}$ pared with the RU-ED or the EU-RD diets $(6.7 \mathrm{~kg} / \mathrm{d})$. This interaction reflected in part the average lower starch concentrations of the EU-RD and RU-ED diets compared with the RU-RD and EU-ED diets (Table 1), and the numerically lower DMI on the RU-ED diet compared with the other diets. Intake of NFC was 0.82 $\mathrm{kg} / \mathrm{d}$ higher on the EU diets than the RU diets. The higher DMI on the EU diets was the primary cause of this effect as NFC concentration was similar across diets.

Nutrient digestibility. Digestibility of DM, N, and NDF tended to be influenced by an S $\times$ RUP interaction $(P=0.10,0.07$, and 0.06 , respectively). When fed the 
Table 3. Least squares means DMI, nutrient intakes, and rumen conditions for primiparous and multiparous Holstein cows fed diets at or above RUP and RDP recommendations.

\begin{tabular}{|c|c|c|c|c|c|c|c|c|c|c|c|}
\hline & \multicolumn{4}{|c|}{ Treatments $^{1}$} & SEM & \multicolumn{2}{|c|}{ Parity } & SEM & \multicolumn{3}{|c|}{$P$ value } \\
\hline $\mathrm{BW}, \mathrm{kg}$ & 578 & 581 & 575 & 577 & 11.6 & 487 & 669 & 16.0 & 0.42 & 0.26 & $<0.001$ \\
\hline $\mathrm{OM}, \mathrm{kg} / \mathrm{d}$ & 20.7 & 22.3 & 19.3 & 21.5 & 1.21 & 16.9 & 24.9 & 1.54 & 0.008 & 0.10 & 0.02 \\
\hline $\mathrm{NDF}, \mathrm{kg} / \mathrm{d}$ & 5.9 & 6.6 & 5.4 & 5.6 & 0.29 & 4.8 & 7.0 & 0.29 & 0.01 & $<0.001$ & 0.005 \\
\hline DM & 65.1 & 65.2 & 65.1 & 66.9 & 1.18 & 65.5 & 65.7 & 1.01 & 0.41 & 0.43 & 0.85 \\
\hline $\mathrm{N}$ & 66.5 & 67.4 & 67.9 & 70.5 & 1.06 & 67.6 & 68.6 & 0.96 & 0.09 & 0.03 & 0.51 \\
\hline $\mathrm{NDF}$ & 43.9 & 45.6 & 44.7 & 42.6 & 2.05 & 44.5 & 43.9 & 1.45 & 0.92 & 0.57 & 0.79 \\
\hline \multicolumn{12}{|l|}{ Rumen measurements } \\
\hline Rumen $\mathrm{NH}_{3}, \mathrm{mg} / \mathrm{dL}$ & 11.6 & 11.8 & 12.3 & 13.1 & 1.35 & 11.9 & 12.6 & 1.31 & 0.72 & 0.44 & 0.63 \\
\hline Rumen $\mathrm{pH}$ & 6.3 & 6.3 & 6.3 & 6.4 & 0.05 & 6.4 & 6.3 & 0.05 & 0.52 & 0.34 & 0.12 \\
\hline
\end{tabular}

${ }^{1} \mathrm{RU}=$ Recommended level of RUP, EU = excess level of RUP, RD = recommended level of RDP, ED = excess level of RDP.

${ }^{2}$ Effect of increasing RUP $=($ EU diets $)$ vs. (RU diets).

${ }^{3}$ Effect of increasing RDP $=(\mathrm{ED}$ diets $)$ vs. $(\mathrm{RD}$ diets $)$.

EU diets, DM digestibility increased by 2.8 percentage units in the multiparous cows ( 64.3 vs. $67.2 \%)$, but decreased by 1.0 percentage units in the primiparous cows (65.9 vs. $64.9 \%)$. For $\mathrm{N}$ digestibility, there was an increase of 3.5 percentage units (66.8 vs. $70.3 \%)$ in multiparous cows, but no change (67.6 vs. $67.6 \%)$ in the primiparous cows. Furthermore, the digestibility of NDF increased 4.0 percentage units ( 41.9 vs. $45.9 \%$ ) in multiparous cows, but decreased 4.3 percentage units (46.6 vs. $42.3 \%$ ) for the primiparous cows, when fed EU diets compared with RU diets. There was an RDP effect on apparent $\mathrm{N}$ digestibility, which was 2.3 percentage units higher (66.9 vs. $69.2 \%$ ) for ED diets compared with RD diets. In contrast, there was an opposite trend with a tendency for higher $\mathrm{N}$ digestibility when cows were fed RU diets compared with EU $\operatorname{diets}$ ( 68.9 vs. $67.2 \%$, respectively).

Rumen measurements. There were no interactions or significant effects of RUP, RDP, or parity on rumen $\mathrm{pH}$ in this study. Although differences in the 24 -h average for rumen ammonia concentration were only numerical, they reflected dietary $\mathrm{CP}$ and in particular, the anticipated RDP supply. There was only a minimal increase in the rumen ammonia concentration for the RU-RD diet compared with the EU-RD diet (Table 3) despite the 1-percentage-unit increase in dietary CP. However, there was a substantial increase in rumen ammonia when comparing the RU-RD to the RU-ED diet (Table 3). Despite a higher dietary CP, ruminal ammonia concentration in the EU-ED diet was expected to be similar to that of the RU-ED diet. In this case however, ruminal ammonia concentration was 0.8 $\mathrm{mg} / \mathrm{dL}$ higher in the EU-ED diet suggesting a greater than anticipated supply of RDP most likely due to higher DMI on the EU-ED diet.

\section{Milk Production and Composition}

Overall average milk production in this trial was $38.8 \pm 8.2 \mathrm{~kg} / \mathrm{d}( \pm \mathrm{SD})$, but milk production was 13.8 $\mathrm{kg} / \mathrm{d}$ higher in multiparous cows than in primiparous cows (Table 4). This difference resulted in fat and true protein yield differences, but there were no differences in the percentage of fat and true protein in the milk between parities.

The absence of $\mathrm{S} \times \mathrm{RUP}$ or $\mathrm{S} \times \mathrm{RDP}$ interactions indicated that milk production response to feeding excess RUP or RDP was not influenced by parity. However, milk production was $1.6 \mathrm{~kg} / \mathrm{d}$ lower on the ED compared with RD diets. In contrast, milk production increased by $1.5 \mathrm{~kg} / \mathrm{d}$ when cows were fed the EU diets compared with RU diets. Milk component yields and percentages were not affected by level of RUP or RDP (Table 4). However, there was a RUP $\times$ RDP interaction for milk fat percentage and yield $(P=0.02$ and 0.02). Milk fat was 0.32 percentage units higher (3.59 vs. $3.27 \%$ ) and $0.13 \mathrm{~kg} / \mathrm{d}$ higher (1.38 vs. $1.25 \mathrm{~kg} / \mathrm{d}$ ) when cows were fed the diets with an excess of either RUP or RDP compared with the diets with recommended RUP and RDP or in excess of both. Urea in the milk was not affected by parity, RUP, or RDP, but it increased numerically with dietary CP.

\section{N Balance}

Daily intake, digestion, and excretion of $N$. In this trial, overall $\mathrm{N}$ intake, milk $\mathrm{N}$, fecal $\mathrm{N}$, urinary 
Table 4. Least squares means milk production and composition for primiparous and multiparous Holstein cows fed diets at or above RUP and RDP recommendations.

\begin{tabular}{|c|c|c|c|c|c|c|c|c|c|c|c|}
\hline & \multicolumn{4}{|c|}{ Treatment $^{1}$} & \multirow[b]{2}{*}{ SEM } & \multicolumn{2}{|c|}{ Parity } & \multirow[b]{2}{*}{ SEM } & \multicolumn{3}{|c|}{$P$ value } \\
\hline & RU-RD & EU-RD & RU-ED & EU-ED & & Primiparous & Multiparous & & $\mathrm{RUP}^{2}$ & $\mathrm{RDP}^{3}$ & Parity \\
\hline Milk, kg/d & 38.8 & 40.6 & 37.4 & 38.6 & 1.51 & 31.9 & 45.7 & 1.91 & 0.06 & 0.05 & 0.002 \\
\hline Milk protein, $\mathrm{kg} / \mathrm{d}$ & 1.00 & 1.07 & 0.99 & 0.99 & 0.05 & 0.85 & 1.17 & 0.06 & 0.32 & 0.19 & 0.01 \\
\hline Milk fat percentage & 3.31 & 3.52 & 3.66 & 3.23 & 0.17 & 3.65 & 3.21 & 0.19 & 0.39 & 0.81 & 0.15 \\
\hline Milk fat, $\mathrm{kg} / \mathrm{d}$ & 1.28 & 1.42 & 1.34 & 1.22 & 0.07 & 1.16 & 1.47 & 0.07 & 0.88 & 0.27 & 0.04 \\
\hline MUN, mg/dL & 11.9 & 12.5 & 12.6 & 13.4 & 0.62 & 12.4 & 12.8 & 0.66 & 0.17 & 0.12 & 0.67 \\
\hline
\end{tabular}

${ }^{1} \mathrm{RU}=$ Recommended level of RUP, EU = excess level of RUP, RD = recommended level of RDP, ED = excess level of RDP.

${ }^{2}$ Effect of increasing RUP $=(\mathrm{EU}$ diets $)$ vs. (RU diets).

${ }^{3} \mathrm{Effect}$ of increasing RDP $=(\mathrm{ED}$ diets $)$ vs. $(\mathrm{RD}$ diets $)$.

$\mathrm{N}$, and NAR were $( \pm \mathrm{SD}) 658 \pm 160,179 \pm 42,210 \pm 57$ $208 \pm 46$, and $61.4 \pm 67 \mathrm{~g} / \mathrm{d}$, respectively. As a reflection of higher DMI, multiparous cows consumed $247 \mathrm{~g} / \mathrm{d}$ more $\mathrm{N}$ than the primiparous cows (Table 5). In contrast, RUP and RDP had a distinctly lesser impact on $\mathrm{N}$ intake, which was $103 \mathrm{~g} / \mathrm{d}$ higher in the EU diets compared with the RU diets and numerically $9 \mathrm{~g} / \mathrm{d}$ lower on the ED diets than the RD diets (Table 5). The former difference was a result of both higher dietary $\mathrm{CP}$ and greater DMI on the EU diets, whereas the latter difference was due in part to the negative effect of the ED diets on DMI (Table 3). The N apparently digested, calculated as $\mathrm{N}$ intake $\times \mathrm{N}$ digestibility, was
$176 \mathrm{~g} / \mathrm{d}$ higher for the multiparous than for the primiparous cows. This difference was more than twice the largest difference due to RUP and RDP, which averaged $83 \mathrm{~g} / \mathrm{d}$ when cows were fed the EU compared with the RU diets. This dietary effect was due both to the higher DMI and to the tendency for higher $\mathrm{N}$ digestibility when cows were fed the EU diets (Table 3).

Fecal N was $72 \mathrm{~g} / \mathrm{d}$ higher in multiparous cows than in primiparous cows. In addition, fecal $\mathrm{N}$ excretion was increased by $21 \mathrm{~g} / \mathrm{d}$ when cows were fed the EU diets compared with the RU diets. In contrast, the ED diets lowered fecal $\mathrm{N}$ excretion by $22 \mathrm{~g} / \mathrm{d}$. Milk $\mathrm{N}$ excretion was $66 \pm 15 \mathrm{~g} / \mathrm{d}$ higher in multiparous cows compared

Table 5. Least squares means $N$ balance for primiparous and multiparous Holstein cows fed diets at or above RUP and RDP recommendations.

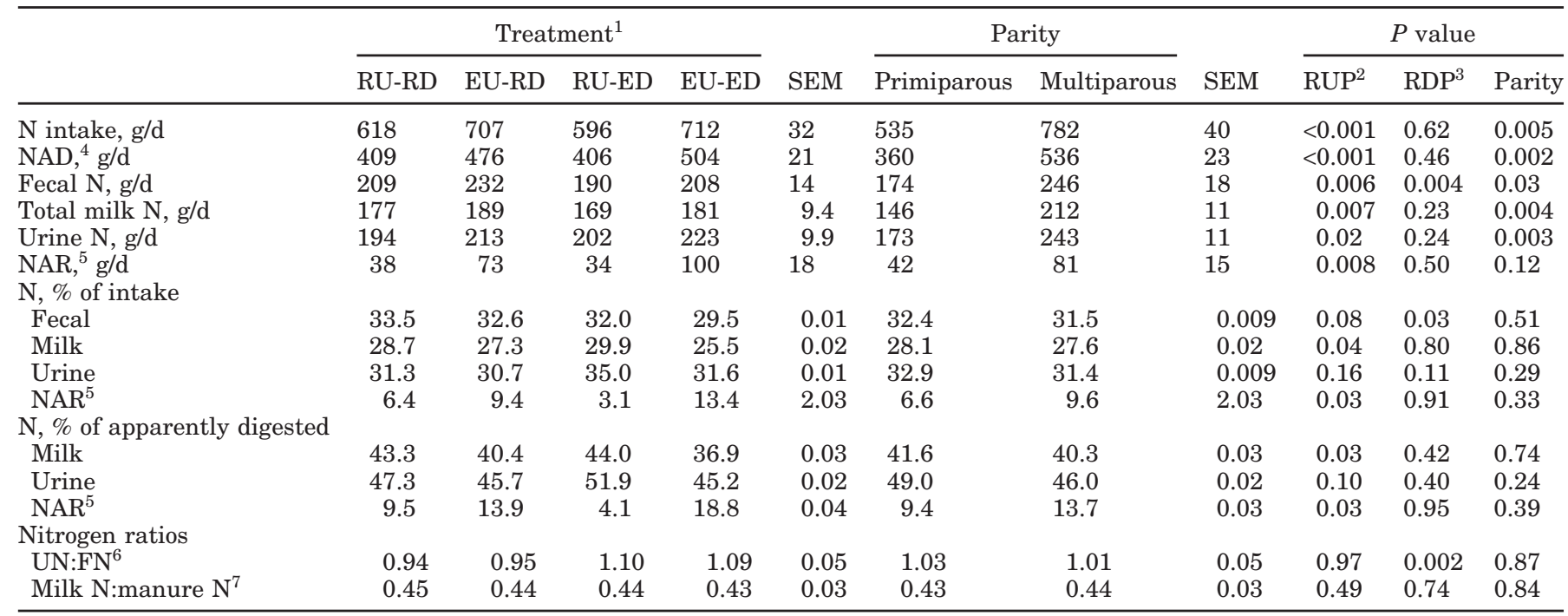

${ }^{1} \mathrm{RU}=$ Recommended level of RUP, EU = excess level of RUP, RD = recommended level of RDP, ED = excess level of RDP.

${ }^{2}$ Effect of increasing RUP $=($ EU diets $)$ vs. $($ RU diets $)$.

${ }^{3}$ Effect of increasing RDP $=($ ED diets $)$ vs. $($ RD diets $)$.

${ }^{4} \mathrm{NAD}=\mathrm{N}$ apparently digested $(\mathrm{N}$ intake $\mathrm{g} / \mathrm{d} \times \mathrm{N}$ digestibility $\%)$.

${ }^{5} \mathrm{NAR}=$ Apparently retained $\mathrm{N}$ calculated as $\mathrm{N}$ intake - milk $\mathrm{N}-$ urine $\mathrm{N}-$ fecal $\mathrm{N}$.

${ }^{6} \mathrm{UN}: \mathrm{FN}=$ Ratio of urine $\mathrm{N}$ to fecal $\mathrm{N}$.

${ }^{7}$ Milk $\mathrm{N}$ : manure $\mathrm{N}=$ ratio of $\mathrm{N}$ in milk to $\mathrm{N}$ in urine and feces. 
with primiparous cows (Table 5). Excretion of $\mathrm{N}$ in milk was not altered when cows were fed the ED diets, but was $12 \mathrm{~g} / \mathrm{d}$ higher on EU compared with RU diets ( $185 \mathrm{vs.} 173 \mathrm{~g} / \mathrm{d}$ ). This positive response to dietary RUP was due primarily to higher milk production rather than a change in milk composition (Table 4). Urine $\mathrm{N}$ excretion tended to be influenced by an $\mathrm{S} \times \mathrm{RUP}$ interaction $(P=0.10)$. There was a larger increase in the urine $\mathrm{N}$ excretion on the EU diets compared with the RU diets for the primiparous cows than for the multiparous cows [33 (190 vs. 157$)$ vs. 7 (247 vs. 240 $\mathrm{g} / \mathrm{d})$, respectively]. Overall, the multiparous cows excreted $70 \mathrm{~g} / \mathrm{d}$ more $\mathrm{N}$ in urine than the primiparous cows. This higher urinary $\mathrm{N}$ excretion was associated with both a higher amount of $\mathrm{N}$ apparently digested and a larger volume of urine excreted (32.2 vs. $20.7 \mathrm{~L} /$ $\mathrm{d}$ for the multiparous and primiparous cows, respectively, $P=0.003$ ). Notwithstanding the interaction just described, overall urine $\mathrm{N}$ excretion was $20 \mathrm{~g} / \mathrm{d}$ higher when cows were fed the EU diets compared with RU $\operatorname{diets}$ (218 vs. $198 \mathrm{~g} / \mathrm{d}$, respectively). Urine volume also increased from 25.7 to $27.3 \mathrm{~L} / \mathrm{d}(P=0.04)$ for the EU compared with the RU diets. In contrast, there was no difference between the ED and RD diets for both urine N excretion (204 vs. 213) and urine volume (26.9 and $26.0 \mathrm{~L} / \mathrm{d}$, respectively, $P=0.20$ ). This result followed the absence of an effect of RDP on the amounts of $\mathrm{N}$ apparently absorbed and excreted in the milk.

The NAR was influenced by the $\mathrm{S} \times \mathrm{RUP}$ interaction $(P=0.03)$. When fed the EU diets, there was an increase in NAR for both the primiparous and the multiparous cows, but the increase was much larger for the multiparous cows (91 vs. $10 \mathrm{~g}$ of $\mathrm{N} / \mathrm{d}$ ). Overall, NAR by the cows was $51 \mathrm{~g} / \mathrm{d}$ higher when fed the EU diets compared with the RU diets.

Feces, milk, urine, and NAR as a percentage of Nintake. In this trial, the percentage of consumed N found in milk, feces, urine, and apparently retained averaged $27.8 \pm 5.4,31.9 \pm 4.1,32.2 \pm 5.4$, and $8.0 \pm$ $9.8,( \pm \mathrm{SD})$ respectively. Although there were no differences in any of these measurements between primiparous and multiparous cows, there was a tendency for an $\mathrm{S} \times \mathrm{RUP}$ interaction $(P=0.07)$ for the percentage of intake $\mathrm{N}$ excreted in the feces. For multiparous cows, there was a decrease of 3.5 percentage units of intake $\mathrm{N}$ excreted in feces (33.2 vs. $29.7 \%$ ), but no change for the primiparous cows (32.3 vs. $32.4 \%$ ) when fed EU compared with RU diets. The level of RUP or RDP influenced the percentage of intake $\mathrm{N}$ excreted in milk, feces, and NAR, but not that excreted in urine (Table 5 ). As reflected by the $\mathrm{N}$ digestibility results presented above, there was a tendency for a lower percentage of intake $\mathrm{N}$ to be excreted in the feces when cows were fed the EU diets compared with the RU diets (31.1 vs.
$32.8 \%$, respectively). Furthermore, there was a decrease in the percentage of $\mathrm{N}$ intake excreted in the feces when fed the ED compared with the RD diets (30.8 vs. $33.1 \%$, respectively). The percentage of $\mathrm{N}$ intake excreted in milk was 2.9 percentage units higher when cows were fed RU compared with EU diets (29.3 vs. $26.4 \%$, respectively). Thus, the efficiency of $\mathrm{N}$ use to synthesize milk $\mathrm{N}$ was higher when cows were fed the RU diets. The percentage of intake $\mathrm{N}$ apparently retained was not influenced by parity but was 6.6 percentage units higher when cows were fed the EU diets compared with the RU diets (11.4 vs. $4.8 \%)$. These results indicated that although there was a lower efficiency of conversion of intake $\mathrm{N}$ into milk $\mathrm{N}$ on the EU diets, there might have been a higher efficiency in conversion of $\mathrm{N}$ into body protein or an alternative $\mathrm{N}$ pool within the body, rather than additional urinary $\mathrm{N}$ excretion.

Milk, urine, and NAR as a percentage of $N$ apparently digested. Parity did not influence milk $\mathrm{N}$, urinary $\mathrm{N}$, and NAR expressed as a percentage of $\mathrm{N}$ apparently digested. However, there was 5.0 percentage units less of the apparently digested $\mathrm{N}$ in milk when cows were fed the EU diets compared with the RU diets. There was a tendency for an $\mathrm{S} \times \mathrm{RUP}$ interaction $(P=0.08)$ indicating that urinary $\mathrm{N}$ excretion expressed as a percentage of $\mathrm{N}$ apparently digested decreased when multiparous cows were fed the EU diets but not for primiparous cows. When fed the EU diets, urinary $\mathrm{N}$ expressed as a percentage of apparently digested $\mathrm{N}$ decreased by 8.5 percentage units in multiparous cows (50.3 vs. $41.8 \%$ for RU and EU diets, respectively) but increased by 0.2 percentage units for the primiparous cows $(48.9$ vs. $49.1 \%$ for RU and $\mathrm{EU}$ diets, respectively). There were no $\mathrm{S} \times \mathrm{RDP}$ or $\mathrm{S} \times$ RUP interactions, but 9.6 percentage units more of the apparently digested $\mathrm{N}$ was apparently retained when cows were fed the EU diets compared with the RU diets.

$N$ ratios. Parity did not influence the urinary $\mathrm{N}$ to fecal $\mathrm{N}$ or the milk $\mathrm{N}$ to manure $\mathrm{N}$ ratios (Table 5). However, the urinary $\mathrm{N}$ to fecal $\mathrm{N}$ ratio increased by 0.15 units when cows were fed the ED diets compared with the RD diets. This is not because of higher urinary $\mathrm{N}$ but rather because of lower fecal $\mathrm{N}$ excretion.

\section{DISCUSSION}

\section{Dietary Balances of RUP and RDP}

The formulated diets had RDP or RUP balance of either 0 or $10 \%$ excess calculated as [100 $\times$ (supplied required)/required]. To further assess the RUP and RDP differences among experimental diets, forage digestion kinetic parameters and actual cow perfor- 
mance (BW, DMI, milk yield, and percentages of protein and fat) were introduced in the NRC (2001) model a posteriori. The average excess RDP in the RD and ED diets was then 4 and 14\%, respectively, but the average excess RUP in the RU and EU diets was 6 and $32 \%$, respectively. The supply of RUP was greater in the EU diet relative to the RU diet because of the higher DMI (Table 3) rather than a change in requirements for milk protein production (Table 4).

\section{RUP and RDP Effects}

As in this trial, Wu and Satter (2000) and Broderick et al. (2002) reported higher DMI when diets with higher levels of expeller soybean meal were fed as a source of additional RUP compared with diets with solvent soybean meal as the primary source of supplemental protein. Our results indicated that this effect was true regardless of parity. Milk production responses to EU diets averaged $1.5 \mathrm{~kg} / \mathrm{d}$ in this trial, $2.8 \mathrm{~kg} / \mathrm{d}$ in Broderick et al. (2002), and $2.7 \mathrm{~kg} / \mathrm{d}$ in Cunningham et al. (1996). The latter study agreed with our findings that this milk production response occurred regardless of parity. Other studies however, reported no difference in milk production with additional expeller soybean meal (Wu and Satter, 2000), formaldehyde-treated soybean meal (Castillo et al., 2001), or animal by-products as the main sources of RUP (Wattiaux et al., 1994; Davidson et al., 2003). In this trial, the ED diets decreased DMI and fecal N but increased apparent digestibility of $\mathrm{N}$ leading to no changes in $\mathrm{N}$ intake or $\mathrm{N}$ apparently absorbed. These effects were true for both primiparous and multiparous cows. Remarkably, milk yield was depressed by $1.7 \mathrm{~kg} / \mathrm{d}$ on the average in both parities when fed the ED diets. This result is consistent with a recent report, which suggested that excess RDP might be detrimental to milk production, particularly in the early part of the lactation (Wattiaux and Karg, 2004b).

\section{Parity Effects}

In agreement with Knowlton et al. (2001), multiparous cows in this trial consumed more $\mathrm{N}$, apparently absorbed more $\mathrm{N}$, and excreted more $\mathrm{N}$ in milk, urine, and feces. Furthermore, our results agreed with those of Davidson et al. (2003) indicating differences in yields of milk, fat, and protein, but no difference in milk fat and protein percentages due to parity. In addition, parity did not influence the efficiency of conversion of dietary $\mathrm{N}$ into milk $\mathrm{N}$ nor the decreased efficiency associated with the EU diets whether milk N was expressed as a percentage of $\mathrm{N}$ intake or $\mathrm{N}$ apparently absorbed (Table 5).

\section{RUP and RDP by Parity Interactions}

In this trial, there were no parity $\times$ RDP interactions, but there were a number of parity $\times$ RUP interactions. The tendency for greater positive responses in apparent digestibility of DM, N, and NDF when fed the EU diets in multiparous relative to primiparous cows was most likely associated with changes in ruminal kinetics despite similar increases in DMI in both parity groups. Unfortunately, this contention could not be verified because no recent studies have reported ruminal passage kinetics and whole tract digestibility responses to increasing DMI in primiparous and multiparous cows.

Parity also influenced the metabolic fate of the additional $\mathrm{N}$ apparently absorbed in response to the EU diets. Only $6 \%$ of the additional $109 \mathrm{~g} / \mathrm{d}$ of $\mathrm{N}$ apparently absorbed was found in the urine of multiparous cows, but $59 \%$ of the additional $56 \mathrm{~g} / \mathrm{d}$ of $\mathrm{N}$ apparently absorbed was found in the urine of primiparous cows. When comparing soybean meal to blood meal, Knowlton et al. (2001) did not detect a dietary CP $\times$ parity interaction for urinary N, but Kauffman and St-Pierre (2001) reported a breed effect (Holstein vs. Jersey). Our results also showed that $17 \%$ of the additional $\mathrm{N}$ was apparently absorbed in primiparous cows but $84 \%$ was apparently retained in multiparous cows. Across all dietary treatments, NAR was $39 \mathrm{~g} / \mathrm{d}$ higher in multiparous than in primiparous cows (Table 5). Factors contributing to this difference may include a greater need to restore body protein reserves mobilized early in lactation (Botts et al., 1979) or a higher urea-N pool in multiparous cows compared with primiparous cows. The latter contention was supported by higher serum urea $\mathrm{N}$ in multiparous than in primiparous cows (data not shown) and the fact that plasma volume increased exponentially with cow BW (Turner and Herman, 1931). Additional contributing factors included experimental error (differential losses of $\mathrm{N}$ from the urine collection carboys) and the additional $\mathrm{N}$ required for scurf, hair, and hoof growth (not measured), but not a differential fetal growth because none of the cows were confirmed pregnant during this trial.

Although the parity difference in NAR was likely biologically meaningful, cautious interpretation is warranted. As is typical, NAR was calculated as N intake minus the sum of milk, urinary, and fecal $\mathrm{N}$. This value (also referred to as $\mathrm{N}$ balance) accumulates the error associated with each of the 4 measurements included in its calculation. As in this trial, many studies with dairy cattle (Castillo et al., 2001; Kauffman and St-Pierre, 2001; Ruppert et al., 2003) have reported positive $\mathrm{N}$ balances with no significant change in BW. Sometimes unrealistically high positive bal- 
ances have been reported. In a meta-analysis of 35 trials with dairy cows, Spanghero and Kowalski (1997) found that the mean and median $\mathrm{N}$ balance were 39 and $24 \mathrm{~g} / \mathrm{d}$, respectively. This phenomenon has been observed in sheep (MacRae et al., 1993) and in pigs placed in respiration chambers (Rasch and Benevenga, 2004). The latter authors reported less than $100 \%$ recovery of ${ }^{15} \mathrm{~N}$ fed to weaned piglets, indicating that there is a nongaseous $\mathrm{N}$-containing excretory product or metabolite that may be escaping detection when total collection is performed.

\section{CONCLUSIONS}

Dry matter intake and milk production increased with increasing RUP (additional expeller soybean meal) in the diets. In contrast, DMI and milk production decreased when the proportion of solvent soybean meal was increased as a way to increase RDP above NRC-predicted requirements. Parity did not influence these responses, the percentage of milk fat and protein, or the efficiency of conversion of dietary $\mathrm{N}$ to milk $\mathrm{N}$. However, the greater increase in NDF digestibility and whole tract apparent digestibility of DM and $\mathrm{N}$ in multiparous cows compared with primiparous cows in response to the same magnitude of increase in DMI suggested differences in the kinetics of digestion across parity. The responses to feeding RUP above the recommended level resulted in a greater increase in urine $\mathrm{N}$ in primiparous than in multiparous cows, but a much greater amount of NAR in multiparous than in primiparous cows. Grouping first-parity cows separately from multiparous cows may contribute more to reducing urinary $\mathrm{N}$ excretion than precision feeding of heterogeneous groups of cows in commercial herds.

\section{ACKNOWLEDGMENTS}

The authors thank S. Bertics for technical assistance, C. Leonardi for assistance and guidance, the staff at the Dairy Cattle Research Center for feeding and care of the cows, and the other Dairy Science graduate students for helping.

\section{REFERENCES}

Association of Official Analytical Chemists. 1990. Official Methods of Analysis. Vol I. 15th ed. AOAC, Arlington, VA.

Association of Official Analytical Chemists. 1999. Official Methods of Analysis. Vol. II. 16th ed. 5th rev. AOAC International, Gaithersburg, MD.

Bal, M. A., R. D. Shaver, K. J. Shinners, J. G. Coors, J. G. Lauer, R. J. Straub, and R. G. Koegel. 2000. Stage of maturity, processing, and hybrid effects on ruminal in situ disappearance in whole-plant corn silage. Anim. Feed Sci. Technol. 86:83-94.

Botts, R. L., R. W. Hemken, and L. S. Bull. 1979. Protein reserves in the lactating dairy cow. J. Dairy Sci. 62:433-440.
Broderick, G. A. 2003. Effects of varying dietary protein and energy levels on the production of lactating dairy cows. J. Dairy Sci. 86:1370-1381.

Broderick, G. A., D. R. Mertens, and R. Simons. 2002. Efficacy of carbohydrate sources for milk production by cows fed diets based in alfalfa silage. J. Dairy Sci. 85:1767-1776.

Castillo, A. R., E. Kebreab, D. E. Beever, J. H. Barbi, J. D. Sutton, H. C. Kirby, and J. France. 2001. The effect of protein supplementation on $\mathrm{N}$ utilization in lactating dairy cows fed grass silage diets. J. Anim. Sci. 79:247-253.

Chaney, A. L., and E. P. Marbach. 1962. Modified reagents for determination of urea and ammonia. Clin. Chem. 8:130-132.

Coblentz, W. K., J. O. Fritz, R. C. Cochran, W. L. Rooney, and K. K. Bolsen. 1997. Protein degradation in response to spontaneous heating in alfalfa hay by in situ and ficin methods. J. Dairy Sci. 80:700-713.

Coblentz, W. K., J. O. Fritz, W. H. Fick, R. C. Cochran, and J. E. Shirley. 1998. In situ dry matter, nitrogen, and fiber degradation of alfalfa, red clover, and eastern gamagrass at four maturities. J. Dairy Sci. 81:150-161.

Cunningham, K. D., M. J. Cecava, T. R. Johnson, and P. A. Ludden. 1996. Influence of source and amount of dietary protein on milk yield by cows in early lactation. J. Dairy Sci. 79:620-630.

Davidson, S., B. A. Hopkins, D. E. Diaz, S. M. Bolt, C. Brownie, V. Fellner, and L. W. Whitlow. 2003. Effects of amounts and degradability of dietary protein on lactation, nitrogen utilization, and excretion in early lactation Holstein cows. J. Dairy Sci. 86:1681-1689.

Goering, H. K., and P. J. Van Soest. 1970. Pages 8-11 in Forage Fiber Analyses (Apparatus, Reagents, Procedures, and Some Applications). Agric. Handbook No 379. ARS-USDA, Washington, DC.

Holm J., I. Bjorck, A. Drews, and N. G. Asp. 1986. A rapid method for the analysis of starch. Starch/Starke 38:224-226.

Karkalas, J. J. 1985. An improved enzymatic method for the determination of native and modified starch. J. Sci. Food Agric. 36:1016.

Kauffman, A. J., and N. R. St-Pierre. 2001. The relationship of milk urea nitrogen to urine nitrogen excretion in Holstein and Jersey cows. J. Dairy Sci. 84:2284-2294.

Knowlton, K. F., J. H. Herbein, M. A. Meister-Weisbarth, and W. A. Wark. 2001. Nitrogen and phosphorus partitioning in lactating Holstein cows fed different sources of dietary protein and phosphorus. J. Dairy Sci. 84:1210-1217.

MacRae, J. C., A. Walker, D. Brown, and G. E. Lobley. 1993. Accretion of total protein and individual amino acids by organs and tissues of growing lambs and the ability of nitrogen balance techniques to quantitate protein retention. Anim. Prod. 57:237-245.

Mertens, D. R. 1999. Variation of NDF results with modifications on the filter bag method. National Forage Testing Association, Technical Session Papers and Committee Reports to the Board and Membership, June 1999, Topeka, KS.

National Research Council. 2001. Nutrient Requirements of Dairy Cattle. 7th rev. ed. Natl. Acad. Sci., Washington, DC.

Rasch, T. W., and N. J. Benevenga. 2004. Recovery of N15 in the body, urine, and gas phase of piglets infused intravenously with ${ }^{15} \mathrm{~N}$ L-alanine from 12-72 hours of age. J. Nutr. 134:847-854.

Ruppert, L. D., J. K. Drackley, D. R. Bremmer, and J. H. Clark. 2003. Effects of tallow in diets based on corn silage or alfalfa silage on digestion and nutrient use by lactating dairy cows. J. Dairy Sci. 86:593-609.

SAS Institute. 1998. User's Guide: Statistics. 7th ed. SAS Institute, Inc., Cary, NC.

Spanghero, M., and Z. M. Kowalski. 1997. Critical analysis of N balance experiments with lactating cows. Livest. Prod. Sci. 52:113-122.

Sukhija, P. S., and D. L. Palmquist. 1988. Rapid method for determination of total fatty acid content and composition of feedstuffs and feces. J. Agric. Food Chem. 36:1202-1206.

Turner, C. W., and H. A. Herman. 1931. A determination of the blood and plasma volume of dairy cattle, a study of blood and plasma volume during growth, pregnancy and lactation. Re- 
search Bull. 159. University of Missouri, College of Agriculture, Agricultural Experiment Station, Columbia, MO.

Van Soest, J. P., J. B. Robertson, and B. A. Lewis. 1991. Methods for dietary fiber, neutral detergent fiber, and non-starch polysaccharides in relation to animal nutrition. J. Dairy Sci. 74:3583-3597.

Wattiaux, M. A., D. K. Combs, and R. D. Shaver. 1994. Lactational response to ruminally undegradable protein by dairy cows fed diets based on alfalfa silage. J. Dairy Sci. 77:1604-1617.
Wattiaux, M. A., and K. L. Karg. 2004a. Protein level for alfalfa and corn silage based diets: I. Lactational response and milk urea nitrogen. J. Dairy Sci. 87:3480-3491.

Wattiaux, M. A., and K. L. Karg. 2004b. Protein level for alfalfa and corn silage based diets: II. Nitrogen balance and manure characteristics. J. Dairy Sci. 87:3492-3502.

Wu, Z., and L. D. Satter. 2000. Milk production during the complete lactation of dairy cows fed diets containing different amounts of protein. J. Dairy Sci. 83:1042-1051. 